\title{
Arthritis by Autoreactive T Cell Lines Obtained from Rats after Injection of Intestinal Bacterial Cell Wall Fragments
}

\author{
Ina S. Klasen, Jeanette Kool, Marie José Melief, Ina Loeve,*

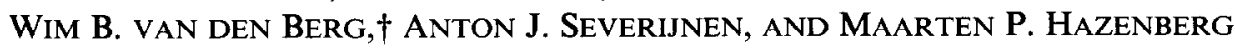 \\ Department of Immunology, Erasmus University, Rotterdam; *Department of Nuclear Medicine, \\ Dijkzigt Hospital, Rotterdam; and †Department of Rheumatology, \\ Sint Radboud Hospital, Nijmegen, The Netherlands
}

Received August 20, 1991; accepted September 10, 1991

\begin{abstract}
$\mathrm{T}$ cell lines (B13, B19) were isolated from the lymph nodes of Lewis rats 12 days after an arthritogenic injection of cell wall fragments of Eubacterium aerofaciens (ECW), a major resident of the human intestinal flora. These cell wall fragments consist of peptidoglycan polysaccharide complexes (PPC). The cell lines that bear the helper phenotype were arthritogenic in knee or ankle joints upon intravenous injection into irradiated Lewis recipients. B13 was, however, not arthritogenic in irradiated F344 recipients that are largely RT1 identical. The arthritis induced in the knee joints of the irradiated Lewis rats was clearly shown by ${ }^{99 \mathrm{~m}}$ technetium-pertechnetate scanning technique and was confirmed histologically. In vitro the cell lines showed a proliferative response after stimulation with syngeneic spleen cells alone. The proliferation was significantly higher when bacterial PPC, isolated in soluble form from normal feces or ileostomy fluid were added. Recognition by B13 appeared to be MHC class II restricted. These results show that autoreactive $T$ cell lines can be isolated from rats after injection of bacterial cell wall antigens and that these cell lines can be arthritogenic. This suggests a role for autoreactive $T$ cells in the induction of bacterial cell wall arthritis and might give a clue for the arthritogenic properties of the normal human intestinal flora. (C) 1992 Academic Press, Inc.
\end{abstract}

\section{INTRODUCTION}

A trigger role for intestinal bacterial antigens in the etiology of rheumatic disease has been hypothesized by Bennett (1) and has been supported by others (2-4). Several observations affirm this hypothesis in man, e.g., the arthritis developing in obese patients after intestinal bypass surgery (5), the arthritis in 15\% of the patients suffering from Crohn's disease (6), and in patients infected with Yersinia, Salmonella, or Shigella (7).

The arthritis-inducing capacity of bacterial antigens and the role of $\mathrm{T}$ cells in the induction of arthritis have been investigated in rat models. In the Mycobacterium tuberculosis $(\mathrm{MT})^{1}$ model, in which Lewis rats develop arthritis upon subcutaneous injection of MT in incomplete Freund's adjuvant (8), a T cell clone (A2b) has been isolated from arthritic rats that was capable of transferring the disease $(9,10)$. The arthritogenic capacity of this $T$ cell clone has been explained by cross reactivity between

\footnotetext{
${ }^{1}$ Abbreviations used: CM, complcte medium; ECW, Eubacterium aerofaciens cell walls; GF, germ-free; MDP, muramyl dipeptide; MT, Mycobacterium tuberculosis; NT, not tested; PPC, peptidoglycan polysaccharide complex; SCW, Streptococcus pyogenes cell walls.
} 
9 amino acids of the $65-\mathrm{kDa}$ heat shock protein of MT and cartilage $(11,12)$. At present, there is more interest in the cross-reactivity between exogenous and endogenous heat shock proteins (13).

In another model using streptococcal cell wall fragments (SCW), Lewis rats are very susceptible to arthritis induction by intraperitoneal injection of SCW (14). Involvement of $\mathrm{T}$ cells in the arthritis induced in this model is clear as chronic arthritis is not inducible in nude rats $(15,16)$ and cyclosporin $A$ has been shown to reduce the severity of the disease (17). A T cell line recognizing both SCW and MT, but not the $65-\mathrm{kDa}$ protein, recently has been found to be arthritogenic in a passive transfer system (18). A correlation between $\mathrm{T}$ cell responses on SCW and the $65-\mathrm{kDa}$ protein has however been described by van den Broek et al. $(19,20)$.

In our model, which is based on the SCW model and the hypothesis stated by Bennett, we have used cell wall fragments from the anaerobic Gram-positive major residents of the human intestinal flora. These bacteria form the largest pool of bacteria with which we are in a lifelong close contact. We have recently shown $(21-24)$ that these cell wall fragments can be arthritogenic after ip injection in Lewis rats. Intraperitoneal injection of peptidoglycan polysaccharide complexes (PPC) of the cell walls of the major resident Eubacterium aerofaciens (ECW), that is present in numbers higher than $10^{10} /$ gram in the human feces, cause a chronic arthritis that lasts for several months and often never wanes completely (22-24). Injection of ECW in IFA in the base of the tail of Lewis rats also induces arthritis (to be-published). Lehman et al. reported on the arthropatic properties of Lactobaccilus species $(25,26)$, while Stimpson et al. chose $S$. facium, $P$. productus, $P$. acnes, and $M$. formicum as representatives of the human indigenous flora (27). These microorganisms, however, do not represent the group of major bowel residents.

PPCs were shown to be present in soluble form in feces of healthy subjects and patients suffering of Crohn's disease (28). PPC isolated from the ileostomy fluid was arthritogenic when $1 \mathrm{mg}$ was injected in the base of the tail in IFA (29).

As we were interested in the capacity of $\mathrm{T}$ cells from arthritic rats in our model, using intestinal bacterial cell wall antigens to transfer the disease, we have made $T$ cell lines using these antigens. The arthritogenic capacities and in vitro characteristics of these $\mathrm{T}$ cell lines, that appear to be different from the lines described above, might give insight into the mechanisms involved in the arthritis caused by intestinal bacterial cell wall antigens.

\section{MATERIALS AND METHODS}

Rats. Lewis and F344 (RT1 ${ }^{\mathrm{l}}$ ) rats were obtained from the Zentral Institute für Versuchstierzucht (Hannover, FRG). RP rats $\left(R^{2} 1 A^{u} B^{1}\right)$ were obtained from the breeding stock of the Erasmus University, Rotterdam, and Wag rats $\left(\mathrm{RT} 1^{\mathrm{u}}\right)$ were obtained from ITRI-TNO, Rijswijk, The Netherlands. Germ-free (GF) F344 rats were obtained from the University of Nijmegen, The Netherlands. Female rats were used at 8-12 weeks of age.

Isolation and maintenance of the $T$ cell lines. B13 was cultured from lymph nodes of five Lewis rats, 12 days after injection of ECW ( $25 \mu \mathrm{g}$ muramic acid/g body wt), B19 came from the LN of a Lewis rat 12 days after injection of $1 \mathrm{mg} \mathrm{ECW}$ in $100 \mu \mathrm{l}$ IFA in the base of the tail. Both were cultured in RPMI 1640 (GIBCO, Paisley, Scotland) with $25 \mathrm{~m} M$ Hepes, $100 \mathrm{U} / \mathrm{ml}$ penicillin, $100 \mu \mathrm{g} / \mathrm{ml}$ streptomycin, $50 \mu M \beta$-mercap- 
toethanol, and 10\% FCS (complete medium (CM)) containing $30 \mu \mathrm{g} / \mathrm{ml} \mathrm{ECW}$ (based on muramic acid content). They were restimulated weekly by dilution in fresh CM and addition of $30 \mu \mathrm{g} / \mathrm{ml} \mathrm{ECW}$ and $3 \times 10^{5}-10^{6} 30.0 \mathrm{~Gy}$-irradiated syngeneic spleen cells (erythrocytes lysed by $155 \mathrm{mM} \mathrm{NH}_{4} \mathrm{Cl}$ with $10 \mathrm{~m} M \mathrm{KHCO}_{3}$, and $10 \mathrm{~m} M$ EDTA for $3 \mathrm{~min}$ at $4^{\circ} \mathrm{C}$ ). Three days later the cells were transferred to CM with $40-100 \mathrm{U} /$ $\mathrm{ml}$ recombinant human IL-2 (recIL-2, kind gift of Dr. J. Besemer, Sandoz, Vienna, Austria). The first two to three restimulation cycles after isolation of the $\mathrm{LN}$, the bulk cultures did not receive recIL-2. The cells were diluted twice a week (at the day of restimulation and at 3 days after restimulation), resulting in a weekly dilution of the cells of about five times.

Proliferation assays. In the proliferation assays $2 \times 10^{4}$ cells per well were tested and $6 \times 10^{4}-2 \times 10^{5}$ syngeneic spleen cells were added in the presence of various antigens. The proliferation assays were performed for 4 days in round-bottom microtiter plates (Costar, Cambridge, UK). In the last $17 \mathrm{hr}$ of culture $7.4 \mathrm{kBq}\left[{ }^{3} \mathrm{H}\right.$ ]thymidine was added (sp act $74 \mathrm{GBq} / \mathrm{mmol}$, Amersham, Buckinghamshire, UK). The cultures were harvested by means of an automatic cell harvester (Costar) and counted in a beta counter (Packard, Brussels, Belgium) or later on in a beta plate (Pharmacia, LKB, Turku, Finland). The results are expressed as the mean counts per minute (cpm) of triplicate cultures \pm standard error of the mean (SEM).

Antigens. Cell wall fragments of ECW and Streptococcus pyogenes (SCW) were prepared as described previously $(14,23)$. PPCs were isolated from the normal human feces or from ileostomy fluid according to procedures described by Hazenberg et al. (28). Muramyl dipeptide (MDP) and concanavalin A (Con A) were purchased from Sigma (St. Louis, MO). The 65-kDa protein was a kind gift of Dr. J. D. A. van Embden, RIVM, Bilthoven, The Netherlands.

Phenotyping of the cell lines. The phenotype of the cells lines was determined by FACScan analysis using ascites of the monoclonal antibodies ER-1, ER-2, Ox-6, Ox8, and ED-1 and culture supernatants of Mark-1 or R73. All monoclonals were a kind gift of Dr. J. Rozing, TNO-IVEG, Rijswijk, The Netherlands. The FACScan analysis was performed of Ficoll gradient-separated cells 3 days after the last restimulation in vitro.

Ankle joint injection. Injection of $15 \mu \mathrm{g} \mathrm{ECW}$ (based on muramic acid content) in $50 \mu \mathrm{l} \mathrm{BSS}$ into the right ankle joint or as a control of $50 \mu \mathrm{l}$ BSS into the left ankle joint was performed under ether anesthesia. The ECW or BSS were administered into the heel of the feet by injection through the Achilles tendon.

Measurement of ankle joint diameter. The diameter of the ankle joints of the hind paws was measured with a vernier caliper.

${ }^{99 m}$ Technetium-pertechnetate scanning. The rats were injected subcutaneously with

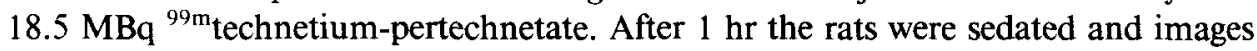
were acquired with a gamma camera fitted with a low-energy all purpose collimator. The images were acquired in a $128 \times 128$ matrix.

Histology. Knee joints were removed and fixed in 4\% paraformaldehyde and decalcified in 5\% formic acid during 2 weeks. Five-micrometer sections were made and stained with hematoxylin and eosin.

\section{RESULTS}

Injection of ECW ip (22-24) or in IFA in the base of the tail (to be published) causes a chronic arthritis that lasts for several months and often does not wane completely. 
We isolated a T cell line (B13) from the peripheral lymph nodes (LN) of Lewis rats 12 days after ip injection of ECW. B19 was isolated from the $\mathrm{LN}$ of a Lewis rat 12 days after injection of ECW/IFA in the base of the tail.

The arthritogenic capacity of B13 and B19 was tested in syngeneic recipients. A summary of the various in vivo experiments is shown in Table 1 . Experiment I shows that ankle joint inflammation was found 6 days after iv injection of $6 \times 10^{7} \mathrm{~B} 13$ cells into 6.0 Gy-irradiated Lewis recipients. The kinetics of the inflammatory swellings of the ankle joints of the rats of Experiment I of Table 1 are shown in Fig. 1. B13 was iv injected into five irradiated Lewis rats. These rats received $15 \mu \mathrm{g}$ of ECW in $50 \mu \mathrm{l}$ in the right ankle joint; $50 \mu \mathrm{l}$ of BSS was injected into the left ankle joint. Another group of irradiated Lewis rats received the same ankle joint injections, but no B13 cells. Injection of ECW into the right ankle joint already resulted in an ankle joint swelling (Fig. 1c). From Fig. 1b, however, it can be seen that also in the left ankle joints where no ECW was injected an inflammation could be found in three out of five of the B13-injected rats. This is the incidence as indicated in Table 1, Experiment I. Local injection of ECW into the right ankle joint without iv injection of B13 did not result in inflammation of the left ankle joint of the rats (Fig. 1d).

In the Experiments II-VII described below, no more additional ankle joint injections were performed.

Joint inflammation was not seen when the recipients were not irradiated (Table 1, Experiment II). Inflammation of the ankle joints was also observed when B13 cells were injected after stimulation for 4 weeks by syngeneic spleen cells alone without additional antigen (Experiment III). No joint inflammation was seen when $30 \mathrm{~Gy}-$ irradiated cells were injected (Table 1, Experiment IV). In Experiment $\mathrm{V}$ the inflammatory swelling was not located in the ankle joints but in the knee joints as was found upon palpation 2 weeks after intravenous injection of $8 \times 10^{7} \mathrm{~B} 13$ cells in five of the seven irradiated (6 Gy) Lewis rats treated. As a knee joint inflammation, because of its location, is not measurable with a vernier caliper we made this inflammation visible

TABLE 1

Summary of the in Vivo Experiments Using B13

\begin{tabular}{|c|c|c|c|c|c|c|c|c|}
\hline Experiment & $\begin{array}{l}\text { Cell } \\
\text { line }\end{array}$ & $\begin{array}{l}\text { No. of } \\
\text { cells }\end{array}$ & $\begin{array}{l}\text { Cclls } \\
\text { irradiated }\end{array}$ & Recipients & $\begin{array}{l}\text { Recipicnts } \\
\text { irradiated }\end{array}$ & Onset & Localization & Incidence \\
\hline I & B 13 & $6 \times 10^{7}$ & - & Lewis & $6.0 \mathrm{~Gy}$ & d6 & Ankles & $3 / 5$ \\
\hline II & B13 & $4 \times 10^{7}$ & - & Lewis & - & - & - & $0 / 5$ \\
\hline III* & B13 & $5.6 \times 10^{7}$ & - & Lewis & $6.5 \mathrm{~Gy}$ & d11 & Ankles & $2 / 5$ \\
\hline \multirow[t]{2}{*}{ IV } & B13 & $7.5 \times 10^{7}$ & - & Lewis & $6.5 \mathrm{~Gy}$ & d11 & Ankles & $2 / 5$ \\
\hline & B13 & $7.5 \times 10^{7}$ & $30 \mathrm{~Gy}$ & Lewis & $6.5 \mathrm{~Gy}$ & - & - & $0 / 5$ \\
\hline V & B13 & $8 \times 10^{7}$ & - & Lewis & $6.0 \mathrm{~Gy}$ & d12 & Knees & $5 / 7$ \\
\hline \multirow[t]{4}{*}{ VI } & B13 & $7 \times 10^{7}$ & - & Lewis & $6.0 \mathrm{~Gy}$ & d7 & Knees (+ ankles) & $5 / 5(2 / 5)$ \\
\hline & B13 & $7 \times 10^{7}$ & - & F344 & $6.0 \mathrm{~Gy}$ & - & - & $0 / 5$ \\
\hline & $\operatorname{Con} \mathrm{A}$ & $6 \times 10^{7}$ & - & Lewis & $6.0 \mathrm{~Gy}$ & - & - & $0 / 5$ \\
\hline & Con $\mathrm{A}$ & $6 \times 10^{7}$ & - & F344 & $6.0 \mathrm{~Gy}$ & - & - & $0 / 5$ \\
\hline VII & B19 & $6 \times 10^{7}$ & - & Lewis & $6.0 \mathrm{~Gy}$ & d14 & Ankles (+ knees) & $2 / 5(1 / 5)$ \\
\hline
\end{tabular}

Note. Cells were iv injected 4 days after restimulation, on day 340-100 U/ml reclL-2 was added. Asterisk indicates that in this experiment the B 13 cells were restimulated for 4 weeks without additional antigen, with syngenous spleen cells alone. Con A cells were LN cells from a naive Lewis rat cultured for 2 weeks on Con A. 


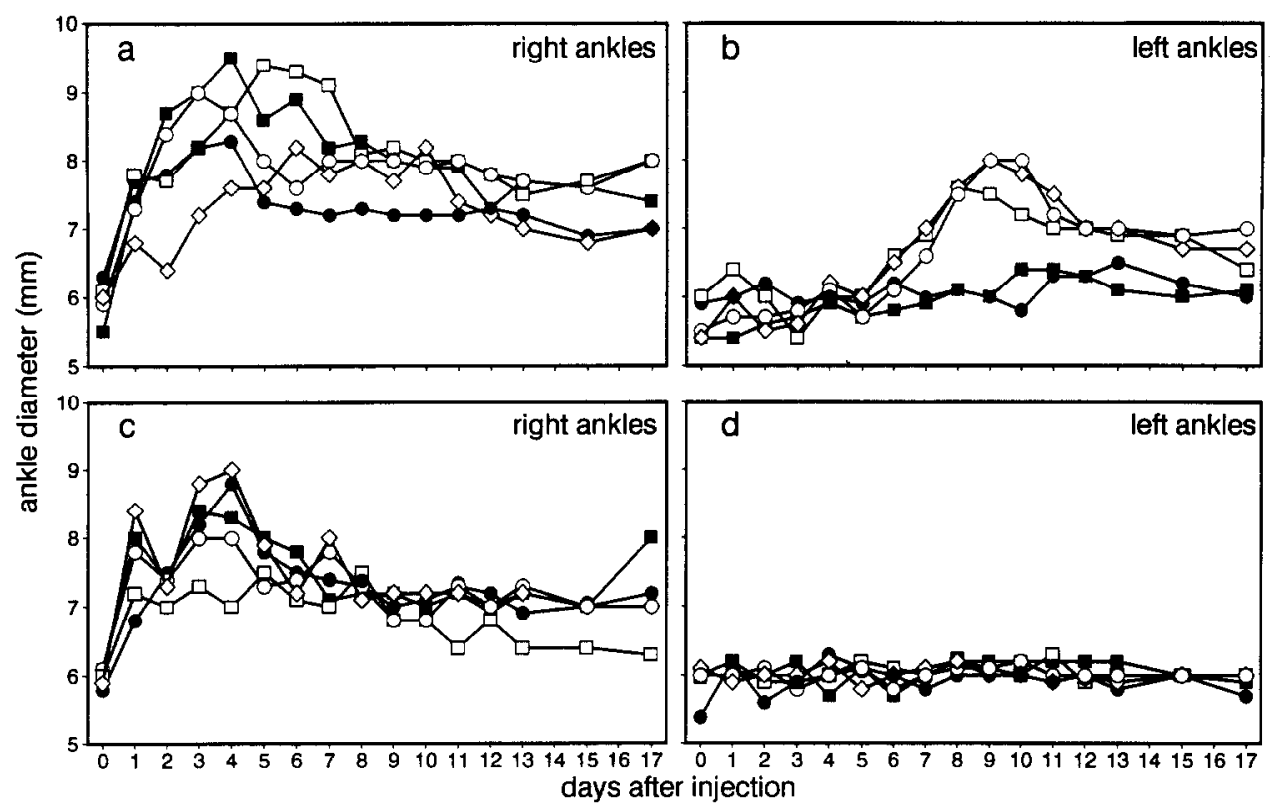

FIG. 1. Ankle diameters of irradiated Lewis rats after iv injection of B13 and local injection of ECW. (a, b) $5.6 \times 10^{7} \mathrm{~B} 13$ cells/rat were iv injected into five irradiated (6 Gy) rats. Into the right ankle joints $15 \mu \mathrm{g}$ of ECW in $50 \mu \mathrm{l}$ and into the left ankle joints $50 \mu \mathrm{l}$ of BSS was injected. (c, d) Five irradiated (6 Gy) rats were injected with $15 \mu \mathrm{g} \mathrm{ECW}$ in $50 \mu \mathrm{l}$ into the right ankle joints and $50 \mu \mathrm{l}$ BSS into the left ankle joints. Ankle joint diameters were measured with a vernier caliper.

by a ${ }^{99 m}$ technetium (Tc)-pertechnetate uptake technique. Two of the arthritic rats of Table 1, Experiment V, were scanned by a this technique at Day 14 after injection of the $T$ cell line. One rat showed a clear swelling in both knee joints (Fig. 2a), whereas the rat of Fig. 2b showed an increased Tc-uptake in the left knee joint, as compared to the scanning pattern of a naive Lewis rat (Fig. 2c). This swelling could not be detected any longer by this scanning method 21 days after injection of B13.

Histological examination of the knee joints of three of the arthritic rats of Exp. $\mathrm{V}$ was performed at Days 13, 15, and 27 after injection of B13. Inflammatory infiltrates consisted of large numbers of mononuclear cells, but also of granulocytes. The bone between marrow spaces was severely damaged and the marrow showed regenerative activity (Fig. 2d). The cartilage appeared practically undamaged. At Day 15 the histology was comparable to that at day 13. At Day 27 there was only a small inflammatory infiltrate left (data not shown).

Injection of Con A-stimulated naive $\mathrm{LN}$ cells into $6 \mathrm{~Gy}$-irradiated rats did not result in disease (Experiment VI). Histological features as described above were also not observed. An interesting observation was made in this experiment (VI). In this experiment the irradiated five Lewis rats all developed knee joint inflammation, whereas none of the irradiated F344 rats that are largely RT1 identical to Lewis rats did. The occurrence of knee joint inflammation correlated with illness and weight loss up to $20 \%$ of the original body weight (Fig. 3). In contrast to the Lewis rats, the F344 rats did not lose weight and administration of Con A-cultured control cells did also not result in weight loss. 

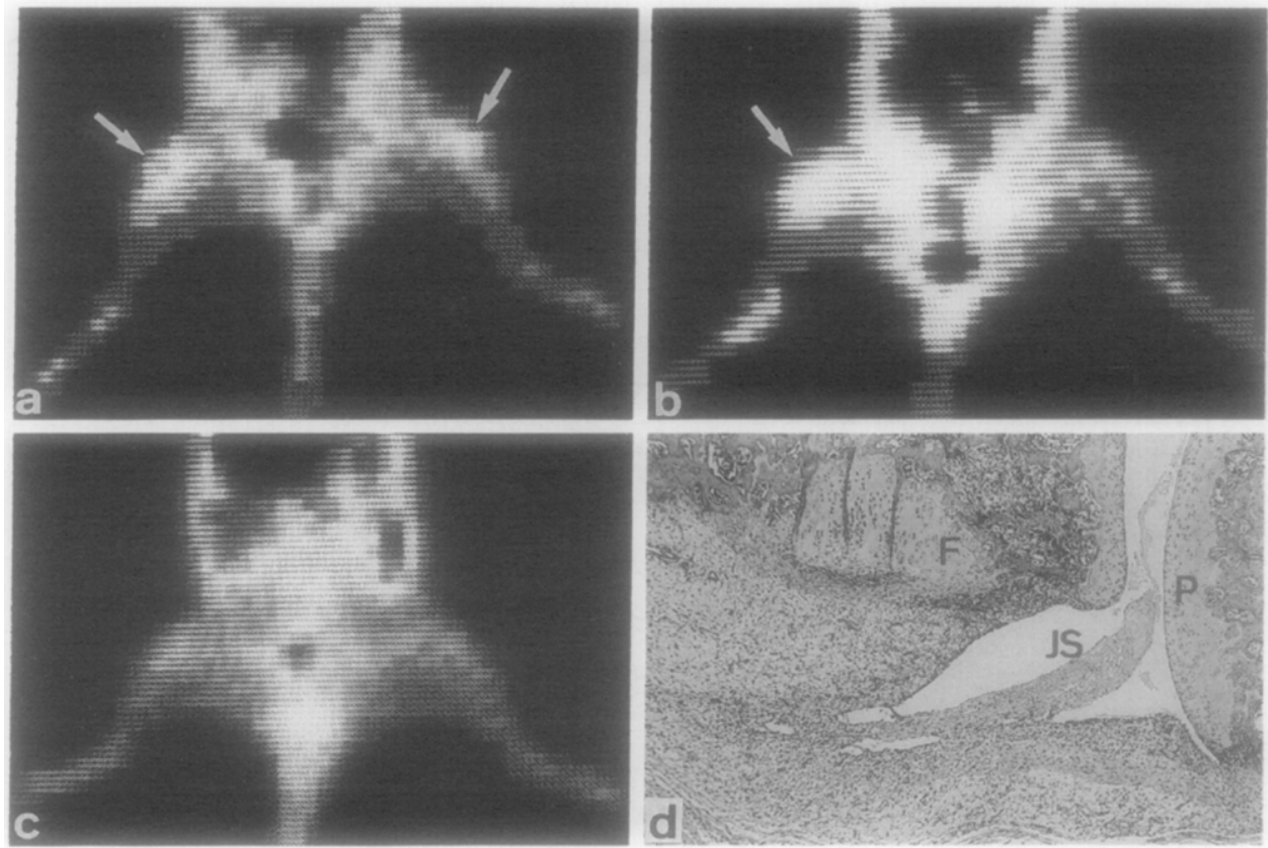

FIG. 2. $(\mathrm{a}, \mathrm{b}, \mathrm{c}){ }^{99 \mathrm{~m}}$ Technetium-pertechnetate scanning of B13-injected rats. $8 \times 10^{7} \mathrm{~B} 13$ cells/rat were injected into seven irradiated ( $6 \mathrm{~Gy}$ ) rats. B13 cells were restimulated for 3 days with $3 \times 10^{5}$ syngeneic spleen cells and $30 \mu \mathrm{g} / \mathrm{ml} \mathrm{ECW}$ and 1 day with additional $40 \mathrm{U} / \mathrm{ml}$ recIL-2. Fourteen days later two of the rats $(a, b)$ and one naive rat (c) were scanned with a gamma camera. The order in the representation of increasing levels of radiation is from black to grey to white. By a computer threshold very high activity levels were eliminated (black in the abdomen). The tails of the rats were used as reference for matching the level of the $\gamma$ radiation emitted by the rats. Rat a suffered from joint inflammation in both knee joints, rat $b$ in the left knee joint (arrows). (d) Histological examination of a knee joint of a B13 injected rat at Day 13 after iv injection of B13. P, patella; F, femur; JS, joint space. Magnification: $40 \times$.

In Experiment VII of Table $1,7 \times 10^{7} \mathrm{~B} 19$ cells were injected. Fourteen days later two of the five rats suffered from ankle joint inflammation. One of these rats also had knee joint inflammation in both knee joints, indicating that B13 was not our only $T$ cell line capable of inducing arthritis.

The helper phenotype of the B13 and B19 cell lines was asserted by FACScan analysis. Both bear an $\alpha \beta$ T cell receptor as they are positive for the monoclonal R73 (30) (Table 2). Three days after restimulation only a small percentage of the cells was class II positive, as was determined by the monoclonal Ox-6 (Table 2). The rather high percentage Mark-1 positive cells might be caused by the presence of irradiated spleen B cells 3 days after the restimulation.

In a proliferation assay the specificity of the cell lines was tested. As shown in Table 3 , extensive proliferation of B13 and B 19 was found when syngeneic spleen cells as a source of antigen presenting cells were added alone. Being aware of the possibility that antigen carry-over could be the reason for this, we cultured the B13 cells for 4 weeks by weekly restimulation with syngeneic spleen cells. At the end of these 4 weeks the cells were diluted about 600 times without the addition of antigen. In a proliferation assay (Table 3, ECW) B13 cells were still found to proliferate on syngeneic spleen cells. Moreover, we were able to culture this B13 cell line continuously for 5 months 


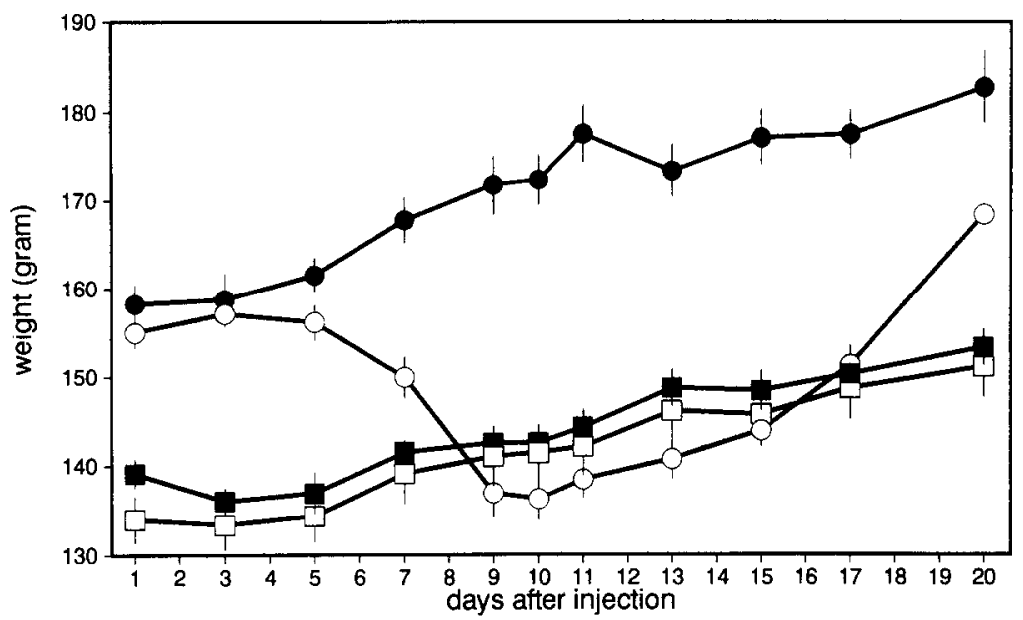

FIG. 3. Mean weights ( \pm SEM) of five Lewis rats after injection of $7 \times 10^{7}$ B13 cells $(O)$, five Lewis rats after injection of $6 \times 10^{7}$ Con A-cultured control cells (-), five F344 rats after injection of $7 \times 10^{7}$ B13 cells $(\square)$, and five F344 rats after injection of $6 \times 10^{7}$ Con A cells (匚). All rats were 6.0 Gy-irradiated.

by a weekly restimulation with syngeneic spleen cells followed by addition of recombinant IL-2 3 days later. Also in serum-free medium (IMDM-ATL (31)) or medium supplemented with $2 \%$ normal rat serum a good proliferation was found on syngeneic spleen cells alone, suggesting that this proliferation is not caused by recognition of a fetal calf serum component (data not shown).

In several experiments we found that addition of intestinal flora derived soluble PPC isolated from normal human feces (28) gave a higher stimulation of B13 or B19 compared to the stimulation by syngeneic spleen cells alone. In Fig. 4a we show the dose-response relationship of the proliferation of the B13 cell line on PPC. A control cell line (naive LN T cells, stimulated for several weeks with Con A) did not respond to PPC, showing that PPC has no mitogenic effect on these cells. Both B13 and the Con A line, however, responded well to Con A (not shown). Moreover, a $T$ cell line reactive with myelin basic protein ( $Z$ line $(32)$ ) was unresponsive to $P P C$ (W. van Eden, personal communication). Figure $4 \mathrm{~b}$ shows the additional stimulation of PPC

TABLE 2

Phenotype of B13 and B19 Determined by FACScan Analysis,

3 Days after the Last Restimulation of the $T$ Cell Lines

\begin{tabular}{llcc}
\hline Monoclonal antibody & \multicolumn{1}{c}{ Marker } & B13\% positive & B19\% positive \\
\hline ER-1 & pan-T cells & 94.2 & 96.4 \\
Mark-1 & B cells & 11.8 & 11.2 \\
ER-2 & CD4 & 90.4 & 92.7 \\
OX-8 & CD8 & 2.4 & 2.2 \\
ED-1 & MØ & 3.2 & 1.9 \\
OX-6 & Class I & 19.4 & 9.1 \\
R73 & $\alpha \beta$ T cell receptor & 86.7 & 96.3 \\
\hline
\end{tabular}


TABLE 3

Proliferationassay of B13 and B19 Cultured with and B13 Cultured without ECW

\begin{tabular}{lcccc}
\hline \multicolumn{1}{c}{ Antigen } & $\mu \mathrm{g} / \mathrm{ml}$ & $\begin{array}{c}\mathrm{B} 13(+\mathrm{ECW}) \\
\mathrm{cpm} \times 10^{-3}\end{array}$ & $\begin{array}{c}\mathrm{B} 13(-\mathrm{ECW}) \\
\mathrm{cpm} \times 10^{-3}\end{array}$ & $\begin{array}{c}\mathrm{B} 19 \\
\mathrm{cpm} \times 10^{-3}\end{array}$ \\
\hline ECW & 30 & $13.6 \pm 0.6$ & $9.3 \pm 2.6$ & $49.1 \pm 3.9$ \\
SCW & 30 & $13.1 \pm 1.0$ & $14.7 \pm 0.2$ & $29.0 \pm 2.1$ \\
PPC & 30 & $27.5 \pm 2.8$ & $12.4 \pm 1.2$ & $50.2 \pm 1.4$ \\
MDP & 30 & $12.1 \pm 3.7$ & $15.7 \pm 2.2$ & $\mathrm{NT}$ \\
65 kDa & 10 & $14.1 \pm 1.7$ & $15.7 \pm 1.2$ & $29.4 \pm 1.6$ \\
Con A & 1 & $16.7 \pm 0.5$ & $14.4 \pm 0.7$ & $58.5 \pm 6.8$ \\
- (syngeneic spleen) & & $19.1 \pm 2.2$ & $13.0 \pm 0.6$ & $29.9 \pm 0.9$ \\
- & & $0.1 \pm 0.0$ & $0.1 \pm 0.1$ & $0.4 \pm 0.1$ \\
\hline
\end{tabular}

Note. $2 \times 10^{4}$ cells per well were tested and $6 \times 10^{4}$ syngeneic spleen cells were added in the presence of various antigens. In the proliferation assay of $B 13$ cells cultured without $\mathrm{ECW}$, the cells were restimulated for 4 weeks by addition of $3 \times 10^{5}$ syngeneic spleen cells $/ \mathrm{ml}$, followed 3 days later by transferring to $\mathrm{CM}$ containing $40-100 \mathrm{U} / \mathrm{ml} \mathrm{IL-2}$. The results are expressed as the mean counts per minute (cpm) of triplicate cultures \pm SEM. NT, not tested.

in a dose-response curve of the syngeneic spleen cells. An additional response by PPC was also observed in the case that high doses of antigen presenting cells were used for stimulation.

As it is possible that the $\mathrm{B} 13$ cell line is a mixture of cells that recognize syngeneic cells and cells that recognize PPC, a subclone of B13 was produced by limiting dilution on syngeneic spleen cells, without additional antigen. The $10 \mathrm{C} 8$ (cloned at 10 cells/ well with a cloning efficiency of $38 \%$, so statistically a clone) showed the same stim-
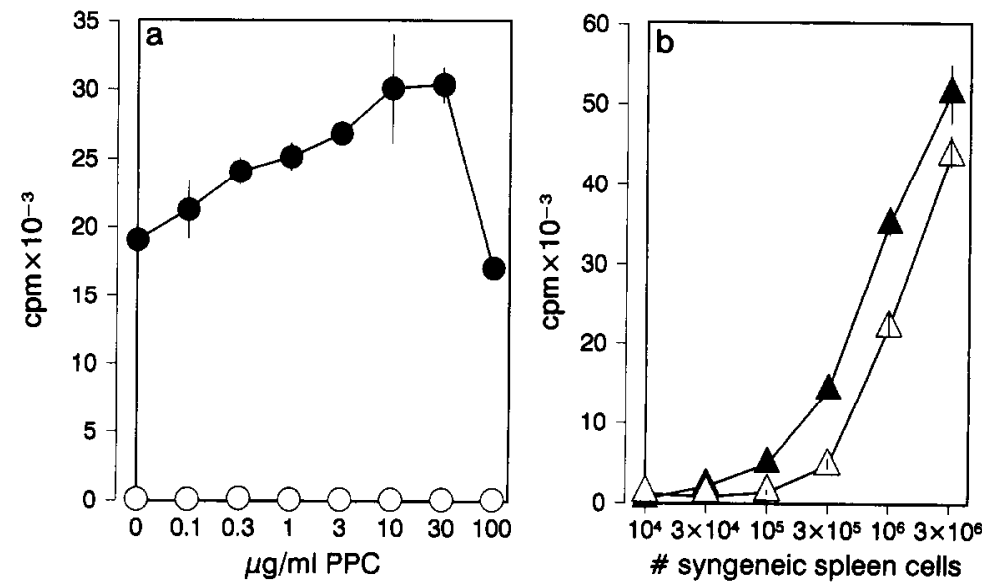

FIG. 4. (a) Dose-response curve of PPC. Proliferation of $2 \times 10^{4}$ cells/well in the presence of various doses of PPC and $3 \times 10^{5} / \mathrm{ml}$ syngereic spleen cells. (O) B13, (O) Con A-cultured LN cells. (b) Doseresponse curve of syngeneic spleen cells. Proliferation of $2 \times 10^{4}$ cells/well in the presence of either increasing numbers of syngeneic spleen cells $(\triangle)$ or with additional $30 \mu \mathrm{g} / \mathrm{ml} P P C(\Delta)$. The results are expressed as the mean counts per minute $(\mathrm{cpm})$ of triplicate cultures \pm SEM. 
ulation pattern as the B13 line (PPC, $7030 \pm 1488 \mathrm{cpm}$; Con A, $10735 \pm 2243 \mathrm{cpm}$; syngeneic spleen cells, $4285 \pm 557 \mathrm{cpm}$; without additional stimulation, $68 \pm 7 \mathrm{cpm}$ ).

Next we determined whether the recognition of the spleen cells and PPC by B13 is MHC restricted. In Table 4 Experiment I, we show that spleen cells from F344 rats, which are also $\mathrm{RT}^{1}{ }^{1}$ like the Lewis rat, but are insusceptible to arthritis induction by bacterial antigens, stimulated B13 as well. Spleen cells from RP rats (RT1 ${ }^{\mathrm{u}} \mathrm{B}^{\mathrm{l}}$ ) also stimulated B13. Wag spleen cells $\left(\mathrm{RT} 1^{\mathrm{u}}\right)$, however, were unable to stimulate $\mathrm{B} 13$, independent of addition of PPC. Addition of syngeneic Lewis spleen cells to the Wag spleen cells again stimulated B13. These results demonstrate that the recognition of spleen cells and PPC by B13 is MHC class II restricted. A third experiment (Table 4, Experiment III) showed that spleen cells from germ-free (GF) F344 rats were also able to stimulate B13.

In conclusion, B13 and B19 are arthritogenic helper T cell lines. B13 shows class II restriction and is additionally stimulated by PPC isolated from the human intestinal contents.

\section{DISCUSSION}

This report describes T cell lines (B13, B19) isolated from Lewis rats, treated with an arthritogenic dose of $E$. aerofaciens. These cell lines cause arthritis after iv injection in irradiated Lewis recipients. Arthritogenic $T$ cell lines have been described that are specific for bacterial antigens. The $\mathrm{A} 2 \mathrm{~b}$ cell line, for example, is directed against the 65-kDa protein of $M$. tuberculosis and is thought to be arthritogenic because of crossreactivity between the $65-\mathrm{kDa}$ protein and cartilage $(11,12)$ or because of cross-reactivity between exogenous and endogenous heat shock proteins (13). An arthritogenic $T$ cell line that recognizes streptococcal cell walls has been published (18) that does

\section{TABLE 4}

Restriction Pattern of B13 and Antigen Presentation by Spleen Cells from Germ-free (GF) F344 Rats

\begin{tabular}{|c|c|c|c|c|c|}
\hline \multirow[b]{2}{*}{ Experiment } & \multirow[b]{2}{*}{ Spleen } & \multicolumn{4}{|c|}{ Antigen cpm $\times 10^{-3}$} \\
\hline & & ECW 30 & PPC 30 & Con A & - \\
\hline \multirow[t]{4}{*}{ I } & Lewis & $24.2 \pm 6.7$ & $40.0 \pm 3.6$ & $29.1 \pm 2.9$ & $39.5 \pm 1.7$ \\
\hline & F344 & $35.5 \pm 3.1$ & $46.6 \pm 3.0$ & $39.1 \pm 3.1$ & $41.5 \pm 0.6$ \\
\hline & RP & $48.2 \pm 1.7$ & $55.1 \pm 2.1$ & $33.2 \pm 2.0$ & $42.1 \pm 3.0$ \\
\hline & - & NT & NT & NT & $1.6 \pm 1.1$ \\
\hline \multirow[t]{4}{*}{ II } & Lewis & $25.2 \pm 0.7$ & $19.4 \pm 0.8$ & $18.1 \pm 1.8$ & $19.7 \pm 1.0$ \\
\hline & Wag & $1.6 \pm 0.6$ & $1.6 \pm 0.1$ & $28.8 \pm 8.2$ & $0.2 \pm 0.1$ \\
\hline & Wag + Lew & $14.4 \pm 0.6$ & NT & $24.3 \pm 1.3$ & $15.3 \pm 0.4$ \\
\hline & - & NT & NT & NT & $0.2 \pm 0.1$ \\
\hline \multirow[t]{3}{*}{ III } & Lewis & $15.8 \pm 1.2$ & $13.1 \pm 2.2$ & $2.0 \pm 0.2$ & $12.8 \pm 0.3$ \\
\hline & F344-GF & $21.1 \pm 1.1$ & $28.0 \pm 2.8$ & $3.6 \pm 0.3$ & $15.6 \pm 0.7$ \\
\hline & - & NT & NT & NT & $0.1 \pm 0.0$ \\
\hline
\end{tabular}

Note. GF F344 spleen cells were used after storage in liquid $\mathrm{N}_{2}$. Spleen cells were tested at $3 \times 10^{5}$ cells/ ml. In the case when Wag and Lewis spleen cells were tested, $1.5 \times 10^{5}$ cells $/ \mathrm{ml}$ of both were pooled. The antigen concentrations used are depicted in $\mu \mathrm{g} / \mathrm{ml}$ in front of the antigen. In this experiment the Con A batch used was not optimal. The results are expressed as the mean counts per minute (cpm) of triplicate cultures \pm SEM. NT, not tested. 
not recognize the $65-\mathrm{kDa}$ protein. The arthritogenic $\mathrm{B} 13$ and $\mathrm{B} 19$ cell lines that are described here differ from those lines as they exhibit a more autoimmune-like character. Autoreactive $\mathrm{T}$ cell lines have also been described by others $(33,34)$, they however did not study the in vivo capacities of these cell lines. The recently described murine autoreactive $\mathrm{T}$ cell line that was shown to recognize the $65-\mathrm{kDa}$ protein of $M$. bovis, as it was additionally stimulated by this protein, is of interest (35). The B13 and B19 $\mathrm{T}$ cell lines that are described here are not additionally stimulated by the $65-\mathrm{kDa}$ protein as can be seen in Table 3 .

Intravenous injection of B13 cells in irradiated Lewis rats resulted in ankle or knee joint inflammation 1-2 weeks after treatment. In two experiments (Table 1, Experiments IV and VII) we saw ankle as well as knee joint inflammation. We cannot explain these differences in location of the inflammation. In the ECW-induced arthritis we also observe that the ankle joint inflammation in some cases is accompanied by knee joint inflammation.

In most of the experiments described in Table 1 the recipients were irradiated sublethally (6.0-6.5 Gy). In the one experiment (Experiment II) in which we did not irradiate the recipients we did not see joint inflammation, but fewer B13 cells were injected there. In the MT model using the A2b T cell line, arthritis was also induced only in irradiated recipients (9).

In order to exclude that the arthritis was induced by bacterial antigen that was still present in the inoculum, and not by B13, we restimulated the B13 cells for 4 weeks by syngeneic spleen cells without additional antigen before iv injection. Table 1, Experiment III, shows that we were still able to induce arthritis in this way. The cells were diluted about 600 times without antigen before in vivo injection. The $5.6 \times 10^{7}$ cells injected per rat were cultured in $200 \mathrm{ml}$ medium originally derived from $0.3 \mathrm{ml}$ culture medium with antigen. Culture medium $(0.3 \mathrm{ml})$ contains $9 \mu \mathrm{g} \mathrm{ECW}$. The cells were washed extensively before injection, so it is unlikely that all the ECW are still present after this treatment. Even if all the ECW would be still present, maximally 9 $\mu \mathrm{g} \mathrm{ECW}$ could be iv-injected in the rats of Experiment III. Moreover, $30 \mathrm{~Gy}$-irradiated B13 did not induce arthritis in Experiment IV, whereas the nonirradiated B13 cells did. In the case that irradiated B13 cells were injected the animals did not show any illness or weight loss, in contrast to the rats injected with nonirradiated B13 cells. This minimizes the probability that the arthritis was induced by bacterial antigens and not by our $\mathrm{T}$ ccll linc.

F344 rats that are also $R T 1^{1}$ as are the Lewis rats, but differ from Lewis rats in the RT6 complex and have been described to differ in their hormonal levels $(36,37)$, are normally insusceptible to chronic arthritis induction by bacterial antigens. This is the case in the $M$. tuberculosis model (38), the $S$. pyogenes model (39), as well as in our model using $E$. aerofaciens (data not shown). It is not clear whether this insusceptibility is caused by the absence of the $T$ cells that are involved in the induction of the arthritis or alternatively by a suppressor mechanism $(40,41)$. We show here that the injection of arthritogenic $T$ cells does not cause arthritis in irradiated F344 rats, favoring the second possibility. It is however not certain whether the Lewis cells can survive in the irradiated F344 rats. We are planning to investigate this in the near future.

In the in vitro experiments we show that $\mathrm{B} 13$ and $\mathrm{B} 19$ proliferate after stimulation with syngeneic spleen cells. B13 could also be stimulated by syngeneic LN cells, thymocytes, or peripheral blood cells (data not shown). PPC, isolated in soluble form from feces, gave an additional stimulation in most experiments. The ECW did not 
show an additional stimulation, probably due to the insoluble character of this preparation.

As B13 is a cell line and not a clone and as we did not observe additional proliferation on PPC of B13 cells cultured without ECW (Table 3, ECW), we cannot exclude here that $\mathrm{Bl} 3$ is in fact a mixture of at least two cell lines, one recognizing syngeneic spleen cells and one recognizing PPC. The proliferation experiment of subclone 10C8, however, showed that the recognition of syngeneic spleen cells and the additional stimulation by PPC was also found at the clonal level. This clone, unfortunately, did not grow well enough to test the in vivo capacities of the cells.

In Table 4 we show the recognition by B13 is MHC class II restricted. The B13 cells proliferated when $R T 1 B^{1}$ was present. The absence of proliferation on $\mathrm{Wag}\left(\mathrm{RT}^{1}{ }^{4}\right)$ cells was restored by addition of Lewis spleen cells, indicating that the B13 cells were still responsive in the presence of the Wag cells.

As it could be assumed that B13 reacts with bacterial antigens, we investigated recognition of spleen cells of GF rats. We used GF F344 spleen cells (GF Lewis rats were not available) that appeared to stimulate B13 also. In sera of these GF rats, however, anti-PPC titers were found (also IgG and IgA) (data not shown), indicating that they meet this antigen, probably due to food constituents. In our opinion these rats are germ-free and not free from bacterial antigens. Moreover, we found that monoclonal antibodies raised against PPC recognize a subpopulation of acid phosphatase positive macrophages in the red pulp of the spleen of these GF F344 rats (to be published).

At present we are investigating the structures that are recognized by B 13 and B 19 on the syngeneic spleen cells. Bjorkman et al. (42) have reported the presence of peptides in the MHC molecules. The T cell lines we describe here might recognize the MHC class II molecules or peptides that are present in the cleft of these molecules. It could be speculated that the recognition by $\mathrm{B} 13$ and $\mathrm{B} 19$ is based on the presence of bacterial antigens such as PPC on antigen presenting cells in vivo. We believe that intestinal PPC is most interesting in the etiology and the pathogenesis of arthritis as humans and animals are in continuous close contact with these antigens and invariably have high antibody titers against these antigens (Hazenberg, personal communication). Our data suggest that Lewis rats are $\mathrm{T}$ cell high responders to these antigens. This is in agreement with our observation that $\mathrm{T}$ cell lines can be isolated from the $\mathrm{LN}$ of naive Lewis rats by culture on syngeneic spleen cells in the presence of ECW or PPC. We are currently investigating the arthritogenic properties of these lines. We were, however, unable to culture $\mathrm{T}$ cell lines in this way from the $\mathrm{LN}$ of arthritis insusceptible F344, neither from naive rats nor from rats injected with ECW. Bulk cultures of LN cells of naive rats weekly restimulated by syngeneic spleen cells without ECW or PPC died after 2 to 3 weeks. We hypothesize that bacterial antigens from the normal endogenous flora can be present in the cleft of the MHC molecule in vivo and can therefore stimulate $\mathrm{B} 13$ and $\mathrm{B} 19$. Racterial cell wall components (muramic acid) can indeed be detected in normal mammalian tissues such as liver, kidney, and brain (43, 44). Granfors et al. $(45,46)$ have published the presence of Salmonella or Yersinia antigens in the joints of patients suffering from joint disease after infection with these bacteria. Bacterial antigens from the intestinal flora, with which we are in lifelong close contact might cause tolerance in the normal situation. After a booster with bacterial antigens this tolerance might be broken. 
In any case the data presented here show that autoreactive $T$ cells can be found after stimulation by intestinal bacterial cell wall antigens and that these $T$ cells can be arthritogenic. This suggests a role for $T$ cells with this type of reactivity in the induction of rheumatic disease.

\section{ACKNOWLEDGMENTS}

We thank Professor Dr. I. R. Cohen, Professor Dr. R. Benner, and Dr. W. H. Bakker for valuable discussion, Miss G. de Korte and Mrs. H. J. Elsenbroek-de Jager for secretarial help, and Mr. T. M. van Os for expert photography. This investigation was supported by the Dutch Rheumatism Foundation.

\section{REFERENCES}

1. Bennett, J. C., Arthritis Rheum. 25, 531, 1978.

2. Inman, R. D., J. Rheumatol. 16, $1017,1987$.

3. Midtvedt, T., Scand. J. Rheurnatol. 64(Suppl.), 49, 1987.

4. Phillips, P. E., J. Rheumatol. 16, 1017, 1989.

5. Ely, P. H., J. Am. Acad. Dermatol. 2, 473, 1980.

6. Greenstein, A. J., Janowitz, H. D., and Sachar, B. D., Medicine (Baltimore) 55, 401, 1976.

7. Keat, A., N. Engl. J. Med. 309, 1606, 1983.

8. Pearson, C. M., and Wood, F. D., Arthritis Rheum. 2, 440, 1959.

9. Holoshitz, J., Naparastek, Y., Ben-Nun, A., and Cohen, I. R., Science 219, 56, 1983.

10. Holoshitz, J., Matitiau, A., and Cohen, I. R., J. Clin. Invest. 73, $211,1984$.

11. Van Eden, W., Holoshitz, J., Nevo, Z., Frenkel, A., Klajman, A., and Cohen, I. R., Proc. Natl. Acad. Sci. USA 82, 5117, 1985.

12. Van Eden, W., Thole, J. E. R., van der Zee, J., Noordzij, A., van Emden, J. D. A., Hensen, E. J., and Cohen, I. R., Nature 331, $171,1988$.

13. Van Eden, W., Immunol. Rev. 121, 5, 1991.

14. Cromartie, W. J., Craddock, J. G., Schwab, J. H., Anderle, S. K., and Yang, C. H., J. Exp. Med. 146, 1586, 1977.

15. Ridge, S. C., Zabriskie, J. B., Oronsky, A. L., and Kerwar, S. S., Cell. Immunol. 96, 231, 1985.

16. Allen, J. B., Malone, D. G., Wahl, S. M., Calandra, G. B., and Wilder, R. L., J. Clin. Invest. 76, 1042, 1985.

17. Yochum, D. E., Allen, J. B., Wahl, S. M., Calandra, G. B., and Wilder, R. L., Arthritis Rheum. 29, 262, 1986.

18. De Joy, S. Q., Ferguson, K. M., Sapp, T. M., Zabriskie, J. B., Oronsky, A. L., and Kerwar, S. S., J. Exp. Med. 170, 369, 1989.

19. Van den Broek, M. F., van den Berg, W. B., Arntz, A. J., and van de Putte, L. B. A., Clin. Exp. Immunol. 72, 9, 1988.

20. Van den Broek, M. F., Hogervorst, E. J. M., van Bruggen, M. C. J., van Eden, W., van der Zee, R., and van den Berg, W. B., J. Exp. Med. 170, 449, 1989.

21. Severijnen, A. J., Hazenberg, M. P., and van de Merwe, J. P., Digestion 39, 118, 1988.

22. Severijnen, A. J., van Kleef, R., Hazenberg, M. P., and van de Merwe, J. P., J. Rheumatol. 16, 1061, 1989.

23. Severijnen, A. J., van Kleef, R., Hazenberg, M. P., and van de Merwe, J. P., Infect. Immun. 58, 523, 1990.

24. Severijnen, A. J., Kool, J., Swaak, A. J. G., and Hazenberg, M. P., Br. J. Rheumatol. 29, 443, 1990.

25. Lehman, T. J. A., Allen, J. B., Plotz, P. H., and Wilder, R. L., Arthritis Rheum. 26, 1259, 1983.

26. Lehman, T. J. A., Allen, J. B., Plotz, P. H., and Wilder, R. L., Arthritis Rheum. 27, 939, 1984.

27. Stimpson, S. A., Brown, R. R., Anderle, S. K., Klapper, D. G., Clark, R. L., Cromartie, W. J., and Schwab, J. H., Infect. Immun. 51, 240, 1986.

28. Hazenberg, M. P., Pennock-Schröder, A. M., Wensinck, F., and van de Merwe, J. P., Eur. J. Clin. Invest. 19, 61, 1989.

29. Kool, J., Ruseler-van Embden, J. G. H., van Lieshout, L. M. C., de Visser, R., Boeye, M. Y., van den Berg, W. B., and Hazenberg, M. P., submitted for publication. 
30. Hünig, T., Wallny, H.-J., Hartley, J. K., Lawetzky, A., and Tiefenthaler, G., J. Exp. Med. 169, 73, 1989.

31. Iscove, N. N., In "Cell Culture Methods for Molecular and Cell Biology" (D. W. Barnes, D. A. Sirbasku, and G. H. Sato, Eds.), pp. 169-185. Liss, New York, 1984.

32. Ben-Nun, A., and Cohen, I. R., J. Immunol. 129, 303, 1982.

33. Zanetti, M., Altman, A., and Rogers, J., Cell. Immunol. 84, 341, 1984.

34. Möller, G. (Ed.), Immunol. Rev. 116, 1990.

35. Matsuzaki, G., Yoshikai, Y., Harada, M., and Nomoto, K., Int. Immunol. 3, 215, 1991.

36. Sternberg, E. M., Hill, J. M., Chrousos, G. P., Kamilaris, T., Listwak, S. J., Gold, P. W., and Wilder, R. L., Proc. Natl. Acad. Sci. USA 86, 2374, 1989.

37. Sternberg, E. M., Young, W. S., Bernardini, R., Calogero, A. E., Chrousos, G. P., Gold, P. W., and Wilder, R. L., Proc. Natl. Acad. Sci. USA 86, 4771, 1989.

38. Kohashi, O., Kawata, J., Umehara, K. Uemura, F., Takahashi, T., and Ozawa, A., Infect. Immun. 26, $791,1979$.

39. Wilder, R. L., Calandra, G. B., Garvin, A. J., Wright, K. D., and Hansen, C. T., Arthritis Rheum. 25, 1064, 1982.

40. Van den Broek, M. F., van Bruggen, M. C. J., van de Putte, L. B. A., and van den Berg, W. B., Cell. Immunol. 116, 216, 1988.

41. Regan, D. R., Cohen, P. L., Cromartie, W. J., and Schwab, J. H., Clin. Exp. Immunol. 74, 365, 1988.

42. Bjorkman, P. J., Saper, M. H., Samraoui, B., Bennet, W. S., Strominger, J. C., and Whiley, D. C., Nature 329, 506, 1987.

43. Sen, Z., and Karnovsky, M. L., Infect. Immun. 43, 937, 1984.

44. Karnovsky, M. L., Fed. Proc. 45, 2556, 1986.

45. Granfors K., Jalkanen, S., von Essen, R., Lahesmaa-Rantala, R., Isomaki, O., Pekkola-Heino, K., Merilahti-Palo, R., Saario, R., Isomaki, H., and Toivanen, A., N. Engl. J. Med. 320, $216,1989$.

46. Granfors, K., Jalkanen, S., Lindberg, A. A., Maki-Ikola, O., von Essen, R., Lahesmaa-Rantala, R., Isomaki, H., Saario, R., Arnold, W. J., and Toivanen, A., Lancet 335, 685, 1990. 